\title{
EVER YDAY RACISM AND RACIALIZED EXPERIENCES AMONG INDONESIAN MIGRANT MUSLIMS IN NEW YORK CITY: PERCEPTION, RESISTANCE, AND SELF-EMPOWERMENT
}

\author{
RASISME DALAM KEHIDUPAN SEHARI-HARI DAN \\ PENGALAMAN PERLAKUAN RASISME TERHADAP \\ MIGRAN MUSLIM INDONESIA DI KOTA NEW YORK: \\ TANGGAPAN, PERLAWANAN, DAN PEMBERDAYAAN DIRI
}

\author{
Diah Irawaty \\ Department of Anthropology \\ State University of New York (SUNY)-Binghamton, New York \\ dirawat1@binghamton.edu
}

\begin{abstract}
This article discusses the daily situations Indonesian migrant Muslims living in New York City (NYC) without legal documents have to deal with regarding racism and racialized experiences. I observe the experiences of the Indonesian Muslim migrants regarding their different social identity, language, religious life, social norms and cultural practices. How do they perceive themselves as immigrants? How do they differentiate themselves from other immigrants? How do they deal with their own identities as immigrants, Indonesians, Muslims and people who belong to one particular ethnic group and as multilingual but non-English speakers? How do they respond to the problems resulting from being immigrants in both ideological discourses and discursive practices? Finally, using the framework of resistance, particularly the so-called empowerment, I explore certain ways these immigrants respond against racism and racialized experiences for both self-survival and self-empowerment as a reflection of their agentive capacity. In particular, I look at how religion and language play a role among the immigrants in their everyday interactions, including in their responses to racism and racialized experiences.
\end{abstract}

Keywords: racism, racialized experiences, migrant Muslims, resistance, self-empowerment.

Abstrak

Artikel ini mendiskusikan bagaimana para imigran Muslim Indonesia di kota New York, Amerika Serikat, menghadapi rasisme dan pengalaman rasis dalam kehidupan sehari-hari. Dengan latar belakang suku, bahasa, pengalaman keberagamaan, dan berbagai norma sosial-budaya yang berbeda, bagaimana mereka membangun identitas tertentu sebagai imigran, yang membuat mereka merasa berbeda dengan para imigran yang lain. Dengan menggunakan perspektif resistensi, khususnya pemberdayaan, artikel ini menganalisa bagaimana para imigran Muslim dari Indonesia tersebut membangun berbagai upaya kritis dalam merespon rasisme dan pengalaman rasis, baik untuk survive ataupun pemberdayaan diri, sebagai salah satu bentuk kapasitas agensi mereka. Secara khusus, saya mengeksplorasi peran penting agama dan bahasa dan identitas etnis dalam upaya resistensi dan pemberdayaan tersebut.

Kata kunci: rasisme, pengalaman perlakuan rasisme, migran Muslim, perlawanan, pemberdayaan diri.

\section{Introduction}

The election of Donald Trump as the $45^{\text {th }}$ President of the United States of America increased public conversations about the situations of immigrants living in the country. Trump employed the issue of immigrants as a powerful weaponto win the presidential race. Inmy view, the way the American people excitedly responded to and accepted Trump's ideas indicates how racism against immigrants still plays a pivotal role in the US political and social realms. My reflection on this hot issue on immigration led me to wonder about some of my colleagues and friends from Indonesia who migrated to the US. How are they? Are they in a good situation?

Prior to the controversy surrounding the immigrant issue, I took for granted the situation Indonesian immigrants living in New York City (NYC) faced; the rise of the public debates really inspired me to understand their lives in more detail.In my personal situation, being an 
immigrant, too, I am really interested in understanding how their life situation is different than mine. What makes our lives different? I want to observe the experiences of these Indonesian Muslim migrants in NYC regarding their different social identity, language, religious life, social norms and cultural practices. How do they perceive themselves as immigrants? How do they deal with their identities as immigrants, Indonesians, Muslims and people who belongto one particular ethnicity and as multilingual but non-English speakers? How do they respond to the problems resulting frombeing immigrantsin both discourses and discursive practices?

In discussing the respondents' reactions to racism, I use the framework of resistance and, particularly, a specific form of resistance, the socalled empowerment in which language plays a role among immigrants in their everyday interactions. I focus on how they deal with and respond to such differences and racism if they experience it and how they see other people's experiences with racism. I also use a theoretical assumption of symbolic interactionism used by Sibai(2015: 21) to see subjective meanings, perceptions, symbols and values created in social interactions in which social reality is a human construction or is socially constructed but always changes.

I use the term race instead of ethnicity to refer to the Indonesian community because, I agree with Bourdieu (1994: 220), ethnicity is used as a scientific euphemismto substitute the idea ofracethat still exists and has been in practices in our lifetime. I deploy ethnicity in this particular context to refer to the local "real" ethnicity based on local ethnic spread in the migrant's hometowns. Indonesian migrants in NYC came from different Indonesian cities, each of which has its own ethnicity, culture, local language and even to some degree its different religion.

Participants in this study originally came from various cities in West Java province. The dominant ethnic group in the province is Sundanese. Some cities have the same local language and some have different dialects and registers. I got participant contacts from my Sundanese friend who used her ethnicitybounded network to help me in doing the field research. Immigrants in this group know each other very well and even live close to each other. They share the same language which helped her to make arrangement for the interview and to organizesmall group interviews or discussions. Two respondents came from Central Java province; their ethnicity is Javanese and they speak the ethnic language called Javanese (Jawa). The other two were from Bali province; their ethnicity is Bali and they speak Balinese as their local language.

These Indonesian migrants did not speak English when they arrived in America and still have limited skill in speaking it. I am interested in understanding how they deal with the situation related to English. In terms of location, I chose NYC because this is a "melting pot" place where people from different countries live and can freelyspeak with their own non-English languages. I am eager to understand how living in such a multicultural context influences experiences related to racism among these Indonesian migrants. Finally, while I found a large number of Indonesian Muslim migrants in the US, especially in big cities like NYC, Los Angeles, San Francisco, Chicago, and Boston, I understand that there is very few studies about their life experiences as migrants.

\section{Migration and the Construction of Individual and Social Identity}

Migration as a result of globalization cannot be avoided. People have the ability and the choice to make decisions about themselves to get better jobs and to have a more decent life for their families. On the one hand, migration creates an opportunity to improve life and make a living, while on the other it creates paradoxes where inequality and injustice, asymmetrical and hierarchical positions as migrants. As they usually come from non-English developing countries to developed countries like the US in which racism and racialization issue are still overwhelming. With English as the dominant hegemonic language and with the monolingualism in the US, migration is a complicated and problematic experience for these immigrants. Indeed, migration is a product and part of globalization where the complexities and dynamics take place (Vigouroux, 2009: 230231). Duchene, Moyer, and Roberts (2013: 7) define migration as "a social of mobility that stems from a wider and more global political and socio-economic order." Migration involves many regimes, institutions, global and local policies, and ideology, and has political social, economic, 
and historical context. Migration is not singular; it is a dynamic process and a contested experience.

Migration to another country is not an experience within empty space where migrants will not encounter social, cultural, political, economic, and religious differences. The problems will become more obvious when migrants have limited social, cultural, linguistic and economic capital and when they hold undocumented status. However, migrants have agentive potential and the power to resist and to empower themselves from all the problems they face. As Duchene, Moyer, and Roberts (2013: 7) argue, immigrants are not passive subjects under powerful social agent's control, but they can use their capacity and strategy to resist. Indeed, migration not only produces a horizontal diversity of cultural and linguistic contact but also feeds into existing and emergent forms of both inequality and conflict (Collins and Slembrouck, 2009: 20).

I refer to De Fina's (2003: 51, 93, 137) definition of identity as expression, representation and negotiation of social roles that can be constructed with regard to self-presentation as well as representation of others in relation to social experiences. Identity is seen to be a categorization process in constructing social identities based on the individual's sense of belonging to groups by which social identity is also part of individual's self-concept going along with value and emotional attachment to the group (De Fina, 2003: 137). The construction of a new identity for immigrants is a crucial part in starting and continuing their lives. How they construct and reconstruct themselves and build self-representation becomes their identity as both individual and group. Self-concept and representation exist because they identify themselves as adifferent group that is usually the vis a vis majority and dominant group. Selfconcept and self-definition createself-identity which is one of the sources deriving from social identification because individual subjects are part of society or collective actors and selfdefinition is not in a vacuum, instead, in the already-defined-world as part of the larger identity space (Friedman, 1994: 117). Therefore, identification as well as classification of groups is the key generator of the construction of individual identities because self-concept of individuals comes from their knowledge of their membership in a particular social groupalong with the social values, ideas, and behaviors ascribed and attributed to it (De Fina, 2003: 137).

I agree with Cohen $(2010: 69,71)$ who follows the study of Brower and Gardner on a tripartite self-construction model of identity about how people negotiate their place in the world through the discursive of manipulations of identity. In this theory, there are three integrated types of self-representation: personal, relational, and collective in which collective identities are integrated into and suppress personal identities. In this paper, I see personal identity as part of the collective one. In collective identities, people can interact and construct themselves on a collective orientation level, which is "further social action for the actualization of one self in the world" (Cohen, 2010: 72).

I want to see how the Indonesian migrants construct their identity as part of their collective identity in a collective orientation, namely their own ethnicity, their religion, and their nationality (country of origin). One aspect that can define our identity is language; it can be used to define a national identity that connects to the origin of nationalism or as a tool to build "imagined communities" (Anderson, 1991) where language is part of the nation and nationalism. For Schmid (2001: 9), language is a powerful instrument to promote, produce and build ethnic and national identity as well as to show power relations between dominant and subordinate groups. It is about power; hence it contributes to values, identity, and a sense of peoplehood that draws the line between "ingroups" and "outgroups."

As national identity, people believe in these values and want to internalize them as part of their collective identity that has to be maintained. Identity re(construction) is a matter of belonging to one particular group. Though individual and collective identities are constructed by self-representation and social categorization (La Barbera, 2015: 2), to me we cannot separate the two, since they overlap and intertwine. As collective identity, people share the same identity and identify themselves as different from others outside the group. The notion of "otherness" has been translated and implemented in daily lives as the beginning of inequalities and social, cultural, national and language differences bringing about pervasive racism and racialization. 


\section{Racism and Racialization}

Racial conflict is one of the biggest problems besides inequality in the US (Pincus, 2006: 51). Some people believe that race is biological or a basic category of human biological variation to refer to racial differences amongst humans. Unfortunately, these differences create and perpetuate racism and racist injustice. Hence, race is not only seen as a biological category, but as a social and political category and reality. Race is a social and political construction and is not a natural category, "an integral part of a classificatory system through which a racialized social order is reproduced and maintained" (Torres, Miron, Inda, 1999: 5). Race plays a crucial role in the construction and production of social differences and group relations created as if they are natural and therefore cannot be changed. (Torres, Miron, Inda, 5).

Some scholars argue that today's racism is a "new racism" because it is not grounded in biological factors, rather it is cultural discrimination (Hill, 2008: 6, 11, 13). Race is based on distinctions that reify cultural distinctions, religious and linguistic, or on the basis of imagined ethnic communities and nationalities (Pagliai, 2011: E96). Hill (2008: 19) addresses white racism and white supremacy as a culture that white supremacists produce and reproduce white racism in language. They share negative stereotypes of other non-white people and become everyday common sense. The ideology of white racism goes along with other social dimensions and has been perpetuated in some influential institutions of privilege, such as education, media, and government to maintain the meanings of whiteness and class privilege (Chun, 2011: 412).

A theory elucidating white supremacy states that "the meaning of whiteness and class privilege folk theory/model" viewing racism is defending white supremacy in which non-white people are considered inferior to whites. Hence, racism is a matter of what white supremacists think and do. In other words, it is individual beliefs, intentions, prejudice and actions and the idea that anyone can be racist (Hill, 6, 8, 18) and it creates color-blind society. White racist ideologies and attitudes have been created to preserve and rationalize white privilege and power (Pincus, 2006: 57). Though the core of racism or racist practices lies at the intentionality in which discrimination and prejudice are the norm, in practiceintention and unintentional are hard to use to determine whether an action/practice is racism or not or the person is being racist or not. Essed (1991: 45, 50), for instance, suggests seeing that the context in which the beliefs and acts work matters because any kind or racism, such as prejudice, discrimination, oppression, or, I add, stereotype and stigma can be tacit or explicit, so any negative actions and practices lead to racism. Intention and intentionality are not unproblematic, they can blur the boundary between intentional and unintentional. Pagliai (2012: 290) raises a good point that there is a tendency about intentions that is often used to defend a speaker from the accusation of racism or of being racist or people's racializing statements. I side with her that people can play around with intentions both to absolve themselves from accusations of racism and to dissociate themselves from racializing discourses and discursive practices. I see the danger of this racializing discourses and practices, specifically when we argue about the intentions that leadto what Dick (2011: 232) calls covert racializing discourses to be able to justify presenting negative views and images of others and also protecting speakers (racists) from racism and prejudice charges. Pagliai (2011: 98) highlights the discussion about intentions is still a subject of debate among scholars.

I would contend that racism is naturalized, internalized and institutionalized, so it becomes part of the everyday life interaction, not only in discourses but also in discursive practices. Racism is an ideology, social practice, system of power that shapes social relations, experience and practices and the process of system itself operating in multiple situation relations, such as gender and class (Essed, 39, 50-51). Racialization turns out to be a mechanism that promotes, reinforces, and sustains racist and racializing discourses at the interactional level, and at the same time they also discourage resistance (Pagliai, 2011: E95). Essed (1991: 38) invites us to see racism at two levels -- macro, which is structural-cultural and micro which is the practices perpetuating the system. I view that Essed proposes to bridge the earlier studies about racism in seeing the distinction between individual and institutional racism that is problematic. His notion of "systemic racism" that he translates into "day-to-day interaction" or everyday racism (Essed, 1991: 37) is similar to 
the idea of Hill and Pagliai (2011) that racism comes to people's lives in many forms through interaction among people relating to the racism as a system and ideology. So, racialization refers to the process by which racial categories are created and (re)produced in people's relationships and interaction creating self and other (Pagliai, 2011: 96). I believe that relationships arenot equal. They are asymmetrical and hierarchical, constructed according to social, political, economic, and ideological purposes. Racism appears to be a dominant ideology based on discourses that emerge with modernity and are connected to the creation of nation states. Like all ideologies, it can influence social action, including the actions of individuals (Pagliai, 2011: 96). Racializing discourses and practices creates exclusion, stratification and boundaries between the self and others (Dick, 2011: 233) and creates racialized images about racism and immigration (Pagliai, 2011: 96).

To support the idea that race is a social construction and social and political fact, almost all human biologists and geneticists agree that "races" and "ethnic groups" take place in everyday language and race is not neutral because it is used by the US government for their own purposes (Hill, 2008: 9). I understand that racialization has dominant hegemonic ideological value that works in every level of life, bringing about social categorization, identity prejudice and social marking that leads to how people think,behave and act towards others who are different (who do not share the same race or ethnicity). Dick (2011: 229) defines racialization as a form of social marking that dehumanizes others and represents them as undifferentiated, immoral and dangerous. There is a process of creation, and maintenance of dominant race creating the ideology and value of whiteness contradicting the value of blackness, the model minority of Asia and Latino as trouble makers.O'Connor (2004: 567) refers to racism as "both to an institutional or social structure of racial domination or injustice-as when we speak of a racist institution-and also to individual actions, beliefs, and attitudes whether consciously held or not, which express, support or justify the superiority of one racial group to another." -

\section{Racialized Language and Language as Ideology}

Language ideologies are a set of language positions representing themselves as forms of common sense that rationalize and justify the forms as well as functions of both talk and text (Hill, 2008: 34). Language becomes the indicator of being and belonging to. The language ideology accompanied by the ideology of "standard" language is made to control the correctness shared by white speakers of American English to maintain White racism (Hill, 2008: 35). One racism target is people who lack English or migrants unable to speak English. Some of them can speak basic English with their own accent and pronunciation or their own grammar, usually called "broken English." Language becomes a crucial element in discussing migration both in public discourses and in discursive practices. De Fina and King (2011: 165) explore the importance of language in migration in the US that connects "English acquisition into the national community," the intolerant attitudes towards other languages and their speakers that occurred as a consequence of the great migration wave of 1880-1924 in which the idea of Americaness, xenophobia and monolingualism became obviously apparent. As a result, English competence and monolingualism is used as a parameter to see integration, assimilation and success among immigrants.

Language has an important and influential role in studies of racism. I view that language is used as a tool to re(produce), support and maintain both the system and the practice of racism in everyday life. However, language itself is an ideology which creates social gaps and unequal social categories perpetuating the idea and practice of racism for such a long time. In the context of migrants, people encounter social differences and interact with their regimes and they also either conform or naturalize it or challenge and resist. Dick (2011: 227) shows that indexical orders give an alternative way to conceptualize the process that leads to covert racializing discourses. She defines it as "the personae indexed by language varieties are stratified." Language as a set of resources is deployed to generate social indexicality. Therefore, language is not neutral, instead it is as well the speaker, are considered inferior (Dick, 2011: 228).

Racism through language as a way of social marking, as raised by Dick, and can be seen in two ways -- racialized remarks targeting directly in conversation where the targeted racism is present or produced during interaction and also indirectly through discourses and 
discursive practices targeting a minority as a subject of communication in which the target of racism is absent. The latter is hard to analyze since there is a tendency of speakers in doing racism as part of upholding face, that is to preserve the conversation and the relationship and to protect the speaker and the other ones' (co-participants') face. She uses Goffman's notion to define face as the person's positive social value during the contact and interaction (Pagliai, 2011: 95), hence it is crucial to maintain the positive image of self and coparticipants during social interactions (Tetreault, 2015: 163) in order to gain face or not to lose face (Pagliai, 2011, E99). Racialized language is a cultural product, rather than a cultural fact in which the relationship between language and race is dynamic (Chung, 2011: 404).

The indexical orders work in the construction of English as a national language and preservation of "white public space," and the production of a monoglot standard resulting standard and good of English and the correctness of English, either in pronunciation, grammar, or accent. (Dick, 230-231). The English-only movement since 1981 was one of the push backs in a multicultural and multilingualism culture and movement. Hence, bilingual or multilingual speech in everyday life becomes a subject of racialization. The standard of English marginalized other people with different accents, dialects or their own way and style in speaking English. Lack of English is also seen as a lack of academics in school experienced by many migrant children, whether born in the US or born in their home of origins like children in Somalia who just started learning English while living in Sheffield, United Kingdom. Their lack of English was considered a dominant factor in lacking in academic ability,and their parents could not provide support or help them with homework (Valentine, Sporton, and Nielsen, 2009: 198-199). Code switching, cross and mixing language is regarded as not part of English purity or "normal and standard English;" so they are targets of prejudice, stigma, discrimination, marginalization, and stereotype. Accent is deployed to make categorization and classification based on place of origin (usually called ethnic or regional identity) with which the people struggle with their identity, their accent, the power in which people make a distinction and to make and unmake groups (Bourdieu, 1994: 221).
I would take two examples to see the racialized language practices from Urcioli's study in Puerto Rican experience and Walter's study in Irish language practices. In the first study, Urcioli raised the issue of English speakers' complaint about the "unfairness" of Spanishspoken in public spaces and in the workplace and neighborhood. In addition, the Puerto Rican accent is considered as influenced by African and Indian, having bad grammar, mixing language. Not only that, their "nonstandard" English spoken is also associated with bad habits, the value of laziness and their speech is not acknowledged as "really language." The judgment made to racialize Puerto Rican Spanish in the US is a form of institutional legitimacy (Urcioli, 1996: 35). The second study comes from radicalization of the Irish in Britain. From their voices and language, Irish people are known as strangers and different from British. There is an ideology working to stereotype Irish as racism targets by equating them as "black" because their "accent" and voices do not follow the British Standard English, so they are considered as "outsiders." This makes them marginalized in the social positioning and class and inferior within the British nation (Walter, 2000: 57-59, 70). From the examples, we can see that language is ideological and political. It is not only an instrument of communication; it is an instrument of control and a source of social identity (Hodge and Kress, 1979: 6, Lippi-Green, 1997: 5).

\section{Resistance and Self-Empowerment}

To understand resistance an action as in the study of Vigouroux, Duchene, Moyer, and Roberts (2008: 17), I use resistance in two ways in this paper, as reaction to power and as a productive way. I also use the framework of resistance as an action in interactional practices and ongoing interactional order, for instance, as a way to resist and challenge institutional regulation, as in Moyer's study. Sabate proposes resistance of migrants through concrete action by utilizing locutorios. In the larger sense as showed by Vigouroux (2008: 17), resistance as an action to resist in a wider national economic order and subversive way in the relationship with regimentation.

I take an example from the book Language, Migration and Social Inequalities to frame my paper and to see the similarities and differences among the studies conducted about 
this topic. Moyer (2013: 196) sees the agency, positioning and resistance of migrants in Barcelona in which language is considered as a valuable resource and, therefore, $r$ access to health care clinics depends on this to be negotiated during patient-doctor interactions. Vigouroux views that learning language or language practices, especially English and a particular local language is a way to improve economic/financial capital in Cape Town. Dalmau's (2013: 249) study reveals another example of locutorios among the community of Catalonia in the Spanish State as sites of social agency and resistance for migrants, especially for undocumented migrants in which they cannot access information and communication technologies (ICTs, specifically mobile phone) because the dominant unfair top-down regulation/immigration policy that gatekeeps migration and migrants. Dalmau (2013: 249) analyzes the space of resistance and empowerment in which migrants mobilize and organize themselves to get access to ICTs by owning their own private company and it plays an important role in bridging and connecting migrants and their families. Locutorios is considered alternative institutions of migration where they can show their social agency.

Another example is from Meinhof and Holly (2009: 180, 193) who focus on integration discourse and everyday narratives as social practices and strategies of bottom-up resistance applied y migrants as a way to react and respond to the national policy or top-down policy discourses in various social contexts. They mention eight resistance strategies but I will only offer one of them, namely self-empowerment. They do not give any definition or explanation about self-empowerment but I would argue that empowerment is a very strong and useful concept to explain agency and power in migrant discourses and discursive practices as part of resistance. I see empowerment, either selfempowerment or collective-empowerment, as part of action of bottom-up resistance, because there is an effort to challenge, resist, and change conditions. Unlike resistance as a reaction to a policy, though migrants challenge and resist the top-down policy in the context of communication or discourse, empowerment (action bottom-up resistance resist in discursive practices or through action or in Vigouroux's term concrete action. O'Connor (2004: 561) views resistance as a response to different dimensions of the systems that can be used either by individuals or collectively. As part of resistance,in my opinion human agency is an important part to analyze in the resistance and self-empowerment framework. Agency, according to Mahmood (2005: 157), is not only a synonym of resistance to social norms but also as a modality of action. Agency, besides positioning and resistance, lies at the heart of Moyer's (2013: 196) work among migrants in terms of the use of language as a valuable resource in a health care clinic in which they try to interact and negotiate.

I disagree with Feagin and Cobas' (2014: 147) distinction between active and passive resistance as part of Latino resistance to white intrusions, insults, and other racialized discrimination because from my perspective we need to give credit for whatever migrants do as part of their struggle. I focus on human and social/collective agency so I believe any response and action are part of their resistance and empowerment. In terms of empowerment, I refer to the assertion in Bayes' (2015: 3) study on empowerment that it should have a substantial impact on humans' ability to controland gainaccess.This can make a real difference in humanexperience and life.

In immigrants' lives, future, and jobs I see how resistance could both be a reaction in a critical way to challenge and produce resistance to dominant discourse. It could be opposition to top-down regulations from the government or local regulations that do not advantage them in any way and either individual or collective action. In this paper, I want to see the strategies used by Indonesian Muslim migrants in NYC to show their individual and collective agency as part of their resistance in both ways, reaction and action in their everyday life, such as in the economy, social interaction, linguistic/language and even cultural and spiritual ways.

\section{Perceptions of Migration and Social Identity}

Most participants see migration as a temporary situation in which they plan to go back to Indonesia at some point. For them, migration is a process of moving from one place to another/from one country to another to get a better life for the individuals themselves and for their families, both in the US and in their home villages. However, there is a willingness to stay permanently in the US if possible, considering that most of their children were born in the US. 
They are concerned with their children's future. Since most of the immigrants came from villages they want their children to have a good education and good English to enable them to get jobs, even in Indonesia. Being able to speak Englishis a strong point for getting a highly-paid job, even in a non-English speaking country because ofthe dominance of English in the world.

As do other immigrants, Indonesian immigrants in NYC have a strong attachment to their homeland. They are aware that they are not American and have a different cultural background. One of the participants in my study said that she likes living in NYC because she can make money on her own and can spend it without asking permission or asking her husband to use it. Besides, she can send some to her family along with some of their belongings or her daughter's belongings. In her home village, she worked on a farm or in wet rice fieldsunder the hot sun heat for virtually nothing, no money, no new and good clothes, no personal belongings. She just lived for survival with limited food. Most participants chose America because they knew the US dollar has a high value compared to the Indonesian rupiah.

In terms of social identity, these migrants see and perceive themselves as different than Indonesian who live in the UStemporarily. Some of them are willing to stay in the US for good since their children are American and most of them cannot speak Indonesian. Some of the parents are passive about speaking Indonesian and most of the children do not understand it at all. The migrants want to preserve their identity as Indonesians, as a particular group of ethnicity, as Muslims and as non-Western people who have a different culture and traditions. However, their intention to stayin the US is part of seeking a better life for their families, so they have to deal with the hardshipsof migrants living far away from their own country and families. If Tetreault (2015: 47) sees Algerian French Arab Muslim teens creating in-group definitions of belonging based on a local construction of linguistic competence focusing on Arabic loan word use, theIndonesian Muslim migrants create their own identity by using in-group definitions of belonging based on their ethnicity in Indonesia. Everybody in Indonesia belongs to a particular ethnicity depending upon where they live. Communalism as well as ethnicprimordialism among them is very strong. We can, therefore,see NYC Indonesian migrants group or classify themselves based on their original ethnicity. The language they use at home, especially between wife and husband, is their local/ethnic language, so ethnicity is a strong connection among them. The ethnic belonging is a tie for their boundedness. The third strong bound is religion; they organize themselves based on the same religion and make some programs to show their identity as Indonesians and Muslims as well as their ethnicity.

\section{Perceptions of Racism}

From the participants, I got lots of information about their own perspective or perception of racism. They believe racism exists, but it depends on our response and attitude towards it. They are aware that the US still has a big problem with racism. According to them, racism happens to people who are not American and white, and is usually experienced by "black" people or people with dark skin as well as by people from different countries, including Indonesia. Female participants who wear hijab added that they heard and knew racism is directed towards Muslim women, especially after the 9/11 tragedy. Nevertheless, wearing hijab is part of their religion, part of their identity as being Muslim, so they will fight for their rights and keep practicing their beliefs.

\section{Experience of Racism and Discrimination by Indonesian Migrant Muslims}

Most of the study participants argue that they do not experience racism because they try to stay away from people, do not interact with them a lot, keep busy and enjoy themselves by connecting with other Indonesians, particularly those with the same ethnicity and religion. They live in peace, keep silentand do not complain, realizing their lack of competence, particularly in language, and they behave in a sense of "do not start arguing." A participant said, "As long as we do not disturb others, they will not disturb us, so do don't provoke and argue and try not to be provoked, try to calm down, just try to be quiet, keep silent and stay away from 'unsafe spaces' that can cause trouble, conflict and uncomfortable feelings and experience." They try not to create any problems, to avoid quarrels and clashes with other people and to not provoke any kind of disharmony. 
Of the12 participants, five (two men and three women -two of whom wear hijab and one who does not) admit having experienced racism and discrimination because of their Asian ethnicity and religious identity. One is a woman who came from Qatar in 2002 to work with her employer's family again, but she could not stand the bad treatment she got from her employer. One day when she had an opportunity to leave her employer she ran away. She started her journey by doing everything by herself with limited English. She said that she got English training for several months before coming to the US but she had never spoken English or been in an English-speaking country. With limited sociolinguistic, cultural and economic capital and with no other resources such as friends and family, she started to survive in NYC as newcomer, a new foreigner who had no idea about American culture, ideology, social political and economic context. She struggled to finda job and tried to contact an Indonesian community or any community with her same ethnicity. Finally, she got a part-time job as a server with a catering company and thus had her own family in NYC.

Compared to other participants' experience, she thought hers was more dramatic and tragic. She experienced racism and racialized statements from the very beginning of her journey in the US. It started with her limited English. Many times, she was treated badly,hearing such words as "stupid," "moron," "no-English Asian," "in America you have to speak English." She really wanted to defend for herself but she could not even say it in English; she just talked to herself and blamed herself for not being able to speak English. She tried to stay calm and not argue though she understood that some people were making fun of her and even insulted her by being racist. Her employer asked her not to wear hijab because he was afraid the customers would not like to see it. $\mathrm{He}$ also wanted to preserve the image of the company since the company was owned by an American and served "American food." She was threatened that if she didn't remove her hijab, she would lose her job. She said, "That situation was such a dilemma for me since I had to make money to pay the rent and other bills and to buy food. If I did not earn money, who was going to pay my bills and feed my family? I had to grant his wish and stop wearing hijab because I did not want to be fired. I felt so guilty because I betrayed my belief and exchanged it for money, but you know
I did not have a choice. If I quit working, it would be hard for me to get another job with you know, not all of employers want to hire people like me (undocumented immigrants) and pay 'under the table.'

She also worked part-time as a cleaner in the laundry business, especially during the weekends. The thing that she did not like was having to go through the subway and take the train. She found the subway a scary, uncomfortable space in which she experienced lots of racialized practices and attitude toward her and discrimination against her as a non-white or woman of color and a Muslim. She got strange looks from people in the subway station and even in on the train. People eyed her from head to toe, and this made her uneasy and uncomfortable. She felt that that it was not fair for her to be treated this way but what could she do? She just tried to control her temper. The situation got worse after the 9/11 tragedy. Many times, she was stopped by the police and asked many questions about her personal identity. She was so scared, especially when she was stoppedby the police so many people stared at her as if she were a terrorist or criminal. Some people thought and said that she was a terrorist. She said, "This is unfair. I am just an ordinary person like others. Why did I have to go through this because I am a Muslim?"

Now she is more confident and does not care about her lack of English or accent though people call her with broken English. She said, "Yes, I have broken English, so what? I cannot speak English well because I am not American, because I do not speak English in my country and my village. How do you expect me to be able to speak English like an American who is born here? That is their own language, they even do not learn that language like me. I speak Indonesian and Sunda (her ethnic language). But when American people come to my country they do not want to learn Indonesian. They speak English." She is right, the dominant hegemonic of English means minorities have been marginalized and suffer.

The second person who admitted to having an unpleasant experience regarding racialized conversations or communicationsas the target of racism during people interaction/ conversation without her being present is a woman from Jakarta. She worked in a travel company in customer service. Her co-workers 
did not like her because she was Asian. Some of them gave her dirty looks and liked to talk about her behind her back. She came with good English skills. Her English is perfect for a nonEnglish-speaking person, especially since she came from a country where English is not the national language. She does not even have an "Indonesian accent." She came to NYC in 2000 and married an American man. They have a son. Some co-workers called her an "ignorance Asian." Some of them even could not distinguish among Asian people; they thought she was from Japan and did not like Japanese people. She was considered Chinese by some. She lived in Savannah, Georgia, before following her husband when he was transferred by his employer. In Savannah, people categorized her based on race. She mentioned that there were three races acknowledged during her stay in the South, namely, Chinese, White, and Black. She was categorized as Chinese. Some people there did not like that she was married to an American. Some stereotypes about immigrants marrying American people were developed. The strange looks from people when she and her husband walked together in public made her very uncomfortable.

The third person was a woman who had just started wearing hijab a year ago. She did not have any racism issues from her employer. She came to the US 14 years ago, with her sister who worked as a domestic worker for an Indonesian who moved to NYC. She now has her own family, with one daughter who was born in America. She works as a housecleaner. She was paid per house on a daily basis, by the homeowner or apartment rent. She said she loves her job because she earns her own moneyand controls it without asking permission from her husband. She also can save her money to send some back home to her family living in the village. She has a big family back there who have limited access to jobs since they live in a small village.

The only problem that she ever had was when she and her daughter played in the playground close their house. A woman came to her and asked her not to talk to her son. In fact, she admitted she never talked to her son. She only talked to her daughter and used the "Indonesian common gesture" by pointing finger to advise her daughter to not to do something that endanger her. The lady was angry and yelled at the Indonesian woman who was not prepared for such a situation since she always distanced herself from crowds and avoided conflict with people. She did not at all expect what happened.She was shocked but tried to explain that she did not talk to the woman's son and did not point a finger at him. The American lady just kept yelling and arguing without listening and made a racialized statement by saying that the Indonesian woman could not even speak English well, "Maybe you don't understand what I am saying." She said that the participant should leave the park because she did not want to be in the same place with her and her daughter. The Indonesian just answered by saying, "I am not American, why do I have to speak English well. At least I try hard to speak English. If you have any problem with my English, just leave me alone." Finally, she chose to leave the playground because the lady just kept arguing on and on. The participant thought that she was uncomfortable being in the public space. What we see in this case is that minorities oftentimes are suspectedof doing something wrong, are always marked and become targets of racism because they are considered as different.They are assumed not to have any right to talk to the majority in public spaces. Language plays an important rolein marking and indexing someone because his or her speech does not meet standard, "normal" English. She is not part of Americanness and white space, so was made to feel uncomfortable when occupying a public space.

In my opinion, in analyzing this second caseit is useful to see Jacquemet's (2014: 202)notion in terms of the context of intercultural communication that has powersaturated context seeing that communication is a contested field and practice that includes power struggles. He identified the power dynamics between the speakers in the communication process in which they have cultural and sociolinguistic expectations and the interactants according to him are aware about the use of language to maintain power and dominance. Gumperz (1982: 131) talks about prosody that can create communicative misunderstanding or communicative breakdown. It is necessary to understand the social cultural context or knowledge conversational inferences as well as "centextualization cues" that are important for signaling contextual presuppositions. If the interactant does not react and is unaware of the cues, misunderstanding could happen (Gumperz, 
132). In this regard, I would include any social, historical and cultural background, and context, tradition and people's expressions and gestures. Conversational inference is "the situated or context-bound process of interpretation, by means of which participants in an exchange assess others' intentions, and on which they base their responses" (Gumperz, 153). In the interpretation process, he sees some intertwined issues that we should pay attention to, such as the physical setting, participant's personal background knowledge and their attitudes toward each other, socio-cultural assumptions, perceptions and expectations pertaining role and social relationships and social values as well as any other factors that can influence and affect the interpretation, such as verbal and non-verbal signs and systems (Gumperz, 153). I would argue that communicative misunderstanding and breakdown, as in the playground case above, can potentially lead to racialized practices in the context of what Gumperz calls "interetnic communication" and interaction or what Jacquemet calls "intercultural communication." Therefore, it is crucial to be aware cultural differences, to understand and pay attention to contextualization cues and conversational inferences to respect one another. In interethnic/ intercultural interaction and communication, if we do not care about the power dynamics and ideology we will slip into everyday racism and racialized practices.

The fourth and fifth cases happened to two Indonesian men. However, they said that what they experienced was just misunderstanding. The first man came to the US a long time ago, when he had just finished high school, to find a job in the US. He came with his uncle. He learned some English before he came to the US but he said that was the first time he had to use his limited English. $\mathrm{He}$ had a traumatic experience in the US airport. He was checked by the customs official andwas very nervous and scared. He was found to be bringing in some strange stuff. The customs officer asked him what he was bringing, showing what they found in his carryon bag. Without thinking he said "Drugs". The customs officer'simmediately turned beet red and he seemed to be mad. The customs officer continued askingwhy the passenger brought it and was told it was because the young man needed it, he used it. He ended up in an isolation room because he was accused bringing in narcotics. He did not know what was going on or what to do. He just kept wondering what was wrong bringing herbal medicine to the US. After several hours, a policeman came and interrogated him and asked where he got the drug. He said bought it from a store in Indonesia. He was getting confused. Finally, the policeman asked him to explain the composition of "the drug". The Indonesian man said it was made from some plants and herbs to cure disease. Then the policeman started to get confused and just checked the composition by reading it from the label. There were some words that the policeman understood from herbal medicine. He said, "Why did you say this was a drug?This is herbal medicine, right?" The young man said yes, people made medicine from herbs. He was released and continued on with his first journey in the US.

The second man's case was also a misunderstanding because he was thought to be a Mexican who worked in a "dirty kitchen" doing "dirty work." He was told to behave, otherwise he would lose his job. He was threatened to be quiet and behave, just working, not causing any problem. The Indonesian man was suspected to be a "trouble maker." He explained that he was not Mexican, he was Indonesian and a chef. The one who mocked and insulted him apologized, saying he did not know the man was not Mexican.But still, he did not give up discriminating against the man, saying, "Are you Asian? Do you speak English?" The Indonesian man just walked from the man who tried to make him a target of racialized remarks and avoided him.

\section{Resistance and Self-Empowerment}

\section{Dealing with Language}

Some of resistancethe participants have in dealing with their lack of linguistic capital, namely English in the context of hegemonic English,did they took some English classes. They believe that by speaking better English they can get better jobsas well as negotiate with their employers about other skills they have, even though some of them are undocumented. They said it is hard to learn another language and it is impossible for them to speak it fluently unless they came to the US as children or were born here. Language is an asset, especially English. It is a valuable resource that can be used for negotiating agency, positioning and resistance (Moyer, 2013: 196-197). They realized if they 
can speak English, even "broken English", they can at least negotiate with their employer, show agreement or disagreement, communicate and be deployed as one of their values as a worker, which is linguistic resources or capital.

One participant even could show her power and agency that according to Moyer by using Ahern's studyis "the socioculturally mediated capacity to act" (Moyer, 198) through her "broken language" or as some call it, "Tarzan language," because Tarzan does not speak "human language". The term also refers to language use based on their own grammar and pronunciation with "non-standard English" as well as the use of gesture. Quoting her, "One day a costumer came to our catering company and wanted to do business with us. She talked to my manager about wanting to order food from us. I was there when the conversation happened. My manager did not understand what she was talking about. It came to my attention and I did understand because she used "Tarzan/broken" language too, just like I do, hahaha...So I came forward and talked to her; we had a conversation. My manager seemed to be confused but I told him about her plan to order food for her party. I felt so good because I could show him that my English is also useful for the company." In this case, we can see the dynamics of the relationship and the appropriation of language change according to the context. English, with its rigid standards and hegemonic power, was not the norm and lost its power when speakers did not share "the standard English." The Indonesian woman showed her individual agency and as part of positioning that the interaction between her and her manager is a dynamic construction in a dialogic and ongoing way (Moyer, 199). Shecould use her positioning and agency to negotiate salary, for instance, or could even use it for not asking her to remove her hijab anymore because she cannot change her belief for money besides the cloth does not have any important function in relations to customers.

Participants also realized that English is a dominant language in the world, with Englishonly regulations, particularly in public service and schools. Consequently, they do not ask their children to learn and speak Indonesian at home. They believe English can determine future success in both education and work for their children. They decided to take English classes and allow their children to speak English at home. After taking some classes they felt more confident though still distanced themselves from wide interaction and communication with people. Some America-born Indonesian children are passive in Indonesian; they understand some Indonesian words but cannot express themselves in Indonesian. Some do not understand it at all and some can say basic words of Indonesian.

All participants said they did not want to push their children to speak Indonesian at home because they are afraid it will affect their English in school and finally they would get bullied by their American friends. They were also worried that their children would fail in school because their potential to be bilingual. They said the American education system is English regulated and English only in class. They considered their children were an asset and resourceto help their parents in dealing with the language barrier. They could even learn from their children. They wished they children could speak Indonesian and their local ethniclanguage, but considering the priority having a better education and good jobs in the future, they preferred English for their children. Nevertheless, they still like using their "broken English" because it is easy for them. They agreed that as long as we understand each other in conversation and communication, nothing matters anymore, because language significance is to communicate. They were proud of using their "broken English" as part of their identity and they also can benefit and utilize their children as linguistic capital and resources in everyday life. I would argue that using their own version of English is also part of their resistance and self-positioning. Their language is their asset and resourceor linguistic capital that can be used as a catalyst between customer and employer who do not share the same "language and language use," so the participant can play a role in filling the gap by showing individual agency as sharing the "same language" with a customer.

\section{Dealing with Religious and "Ethnic" Identity}

In dealing with religious, cultural and ethnic differences, those participants empower themselves by utilizing a mosque (masjid) called Al-Hikmah mosque dedicated on August 17, 1995, coinciding with the celebration of the $50^{\text {th }}$ anniversary of Indonesian Independence 
Day ${ }^{1}$. Masjid Al-Hikmah was established as their own space which they can occupy freely without competing and arguing with others and as part of building their sense of belonging and identity as an Indonesian Muslim community. In public space where lots of prejudice, stigma, stereotype and discrimination can happen any time, in this mosque they can meet some Indonesian friends,including from the same ethnic background. Because people in Indonesia are multilingual, they do not have problem in expressing themselves in their local languages. Besides for praying, this mosque mediates some activities, such as food bazaar, sermon (da'wah), learning Islam, Islamic history, learning Arabic, and reciting the Qur'an.

Masjid Al-Hikmah also conducts community activities, especially for those who are Indonesian Muslims in NYC. Masjid AlHikmah offers Saturday School, in which elementary and middle school children can learn about Islam. Currently, with more than one hundred students, of which some are nonIndonesians, it also provides social services, such as wedding ceremonies, interfaith dialogues, bazaars ${ }^{2}$, charity programs and other humanitarian programs. Some Indonesian students have initiative to make program for America-born Indonesian learning Indonesian language and Indonesian culture. They offer Indonesian class for Indonesian children who want to speak Indonesia. They also sometimes collaborate with the Indonesian Embassy in NYC to make some programs. They make connection with other Muslims from other countries who help to provide a teacher to teach Islamic studies and Qur'an recital so the children still can have the connection with their religious background. Participants also use their local language, besides Indonesia at home to introduce to their children. Another activities related to their ethnic background community gathering among ethnic groups and food festival called "uniting the cultures of Indonesian through food"3.

\footnotetext{
${ }^{1}$ http://macaulay.cuny.edu/eportfolios/drabik 10 website/neighborhoods-2/astoria/astoria-houses-ofworship/masjid-al-hikmah/).

${ }^{2} \mathrm{http}: / /$ macaulay.cuny.edu/eportfolios/drabik 10website/neighborhoods-2/astoria/astoria-houses-ofworship/masjid-al-hikmah/

${ }^{3} \mathrm{https}$ ://voicesofny.org/2016/08/uniting-thecultures-of-indonesia-through-food/
}

\section{Dealing with Economic Situation}

Below are some mechanisms these migrant assign to deal with economic issues. Using their "cultural capital" as defined by Meinhof (2009: 151) as available cultural resources for individuals obtained through socialization, education, professional development and training that can be used to get economic capital, such as individual and professional skill in cooking and knowledgeable about food to negotiate. They break the stereotype about laziness among migrants or stigma that migrant with lack of English skill will not succeed in their workplace. They prove it that they are hard worker. This is a form of resistance they showed.

The other way to sustain their life in the US is that they build informal network by appropriating Indonesian mosque to exchange information about job. People can share any information regarding any possibility to work. They also create a group through social media for job occupation in NYC surrounding either for documented and undocumented migrants, sellused and new stuffs, rent rooms, and do charity activities.

Another way to findjobs is through word-of-mouth and use their community or religious gathering or home visit to find and share information about job. For undocumented migrants, they have to seek job with cash payment which is a little bit harder,though as they live in big city of NYC it is still possible to get job.They also use the opportunity and take advantage of being Asian by finding jobs in Asian restaurants.

Another important thing that they do in dealing with economic situation is creating job for themselves to improve their economic condition, so they can meet their ends and send some money back home to their family living in the village by practicing what Vigouroux (2013: 226) terms as "informal economy." For undocumented migrants who lack of financial capital, have limited education, and lack of English competence as well as professional skills, they creatively see the opportunity and take advantage living in the big city like NYC. Here is some example of it.

They start their own business by selling fresh and homemade food, cookies, cake, bread, etc. Some also sell cloth and what they consider as "Muslim and Muslimah (women Muslim) 
clothes," hijab in various models and mukenah (specific cloth for praying used by Malays, such as Indonesia, Malaysia and Singapore Muslimah/ $u k h t i)$. Economic empowerment is another form of migrant resistance to make extra cash in struggling finding job in formal economy. By appropriating Lautier's (2011: 232) notion, Vigouroux mentions that access to informal economy for migrant shows that the job they create is not only as an alternative for them as struggle and failure of entering formal economy but also the job gives them privilege of being independent worker.

Participants use their own network to offer babysitting job to each other with negotiated fee. It will help them taking care of their children after school when they work. There is also benefit they would get if they send their children to Indonesian family which there is always food available for free for the children because Indonesian like cooking every day and sharing food. They do not need to worry about food. They can bring lunch box along with their children but if they do not have a chance to cook, food will be available any time. Another thing they do is offering service for teaching children how to recite Qur'an and Islamic studies, learning Indonesian, etc. However, the fee is negotiable based on their income and ability to pay because they have close connection. Sometimes even free of charge as part of helping each other. Part of their reciprocity they do the same thing as helping without expectation to charge the service. I would argue what do also as part of their agency, power and resistance toward commoditization of babysitting for instance; they find their own way. Besides they cannot trust any people who they do not know yet to babysit their children. It is obviously much cheaper, sometimes free and along with food available any time. Most of informal activities and using cultural capital to benefit economic capital do by women. In this context, women are more creative in making money, finding the way to survive in economic life.

\section{Dealing with Communication and Social Interaction}

To deal with everyday social interaction, they had a motto, "I am a nice person and interested in nice people too; I will not disturb you and leave you alone but you also have to leave me alone and do not disturb me because we want peace and live in harmony without conflict. So, let me do my own way and you do your own." They try to believe it and internalize and practice it in their everyday interaction. Yet, it does not mean that they do not interact with people. I see the way they deal with this matter seems to be a form a resistance to show that they are nice people and do not want to cause any trouble. Though it does not guarantee that it can circumvent conflict and being target of racism but they try their way as much as possible to avoid it. They said they do not mean that other people who get racism and being target of racialized practices because of their fault in terms of attitude or provoking conflict, etc. They just find the way not to deal with it.

They try to keep busy by making connection with others, especially with other migrants, Indonesian friends, and some nice and friendly American friends. They make some activities, such as community gathering, home visit and doing activities together like cooking and eating together, picnic, cultural event, family hanging out together. They try as much as they could to get away from people and avoid conflict with others, stay away or distance, keep silencing, and calm down. They also like to maintain the connection with others by inviting them to have lunch or dinner or to hang out together, to arrange playdate for their children As part of their resistance, in some degree there is a tendency that some participants "blame" black community as source of chaos and crimes. However, people mixed up between black people and other people of color or non-black people who do not share the same habits and stereotypes. Participants see sometimes they cannot control their attitude, behave and be nice. Lots of experience they face as a consequence of what "black community" have done such as stealing, throwing garbage anywhere, talking so loud, asking money, etc. Finally, participants said that they are affected by black community behavior of being blamed as foreigners and migrantswho createand bringproblems in the US.

\section{Closing Remarks}

The experience of transnational migration among Indonesian Muslims in NYC provides a very dynamic situation of migrants from nonspeaking English with Islamic identity deal with everyday racism and racialized experience. While these linguistic and religious backgrounds often encouraged incident of racism and racialized experiences in daily basis, the 
Indonesian Muslim migrants in NYC also had certain coping mechanisms that indicate their empowering and agentive bottom up resistance at both individual-personal level and collectivecommunity level. To some extent, within this dynamic situation, we can find various success stories among these migrants both in dealing with everyday racism and racialized experiences and in making a living.

\section{Bibliography}

Anderson, Benedict. (1991). Imagined Communities. London, New York: Verso.

Bayes, Jimmy. (2015). Empowerment: Understanding the Theory behind Empowerment. Bryan, TX: Dunamis Publications

Blum, Lawrence. (2003). Antiracism, Multiculturalism, and Interracial Community: Three Educational Values for a Multicultural Society. In Heldke, Lisa and O'Connor. (Eds). Oppression, Privilege, and Resistance: Theoretical Perspective on Racism, Sexism, and Heterosexism. New York: McGraw-Hill Humanities, pp. 564-582.

Bourdieu, Pierre. (1994). Language and Symbolic Power. Cambridge, MA: Harvard University Press.

Chun, E. (2011). Reading Race Beyond Black and White. Discourse \& Society, Vol. 22 (4), pp. 403-21.

Cobas, Jose A, Feagin Joe R. (2014). Latinos Facing Racism: Discrimination, Resistance, and Endurance. Boulder, London: Paradigm Publishers.

Dalmau, Maria Sabate'i. (2013). Fighting Exclusion from the Margins: Locutorios as Sites of Social Agency and Resistance for Migrants. In Duchene, Alexandre, Moyer, Melisa and Roberts, Celia (Eds.). Language, Migration and Social Inequalities: A Critical Sociolinguistic Perspective on Institutions and Work. Bistol, Buffalo, Toronto: Multilingual Matters, pp. 248-271.

De Fina, Anna. (2003). Identity Narrative: A Study of Immigrant Discourse. Amsterdam, Philadelphia: John Benjamins Publishing Company.

De Fina, Anna and King, KA. (2011). Language Problem or Language Conflict? Narratives of Immigrant Women's Experiences in the US. Discourse Studies, Vol. 13 (2), pp. 163-88.

Dick, Hilary Parsons. (2011). Language and Migration to the United States. Annual Review of Anthropology, Vol. 40, pp. 227-240.

Duchene, Alexandre, Moyer, Melissa and Roberts, Celia. (2013). Introduction: Recasting Institutions and Work in Multilingual and Transnational Spaces. In Duchene, Alexandre, Moyer, Melisa and Roberts, Celia (Eds.). Language, Migration and Social Inequalities: A Critical Sociolinguistic Perspective on Institutions and Work. Bistol, Buffalo, Toronto: Multilingual Matters, pp. 1-24.

Duranti, Alessandro. (1997). Linguistic Anthropology. Cambridge: Cambridge University Press.

Essed, Philomena. (1991). Understanding Everyday Racism: An Interdisciplinary Theory. Newbury Park, London, New Delhi: Sage Publications.

Friedman, Jonathan. (1994). Cultural Identity \& Global Process. London, Thousand Oaks, New Delhi: SAGE Publications.

Gumperz, John. J. (1982). Discourse Strategies. Cambridge: Cambridge University Press.

Hill, Jane H. (2008). The Everyday Language of White Racism. Malden, MA: WileyBlackwell.

Hodge, Robert and Kress, Gunther. (1979). Language as Ideology. London, New York: Routledge.

Holly, Werner and Meinhof, Ulrike Hanna. (2013). 'Integration Hatten wir Letztes Jahr': Official Discourses of Integration and Their Uptake by Migrants in Germany. In Duchene, Alexandre, Moyer, Melisa and Roberts, Celia (Eds.). Language, Migration and Social Inequalities: A Critical Sociolinguistic Perspective on Institutions and Work. Bistol, Buffalo, Toronto: Multilingual Matters, pp. 171-195.

Jacquemet, Marco. (2005). Transidiomatic Practices: Language and Power in the Age of Globalization. Language and Communication, Vol. 25 (3), pp. 257-277.

La Barbera, MariaCaterina. (2014). Identity and Migration in Europe: Multidisciplinary Perspectives. London, New York: Springer. 
Lippi-Green, Rosina. (1997). English with an Accent: Language, Ideology, and Discrimination in the United States. London, New York: Routledge.

Mahmood, Saba. (2005). Politics of Piety: The Islamic Revival and the Feminist Subject. Princeton and Oxford: Princeton University Press.

Meinhof, Ulrike Hanna. (2009). Transnational Flows, Networks, and Transcultural Capital': Reflections on Researching Migrant Networks through Linguistic Ethnography. In Collins, James, Sembrouck, Stef and Baynham, Mike (Eds).Globalization and Language Contact: Scale, Migration, and Communicative Practices. London, New York: Continuum.

Moyer, Melissa G. (2013). Language as a Resource, Migrant Agency, Positioning and Resistance in a Health Clinic. In Duchene, Aexandre, Moyer, Melisa and Roberts, Celia (Eds.). Language, Migration and Social Inequalities: A Critical Sociolinguistic Perspective on Institutions and Work. Bistol, Buffalo, Toronto: Multilingual Matters, pp. 196-224.

Pagliai, Valentina. (2011). Unmarked Racializing Discourse, Facework, and Identity in Talk about Immigrants in Italy. Journal of Linguistic Anthropology, Vol. 21 (1), pp. E94-E112.

Pagliai, Valentina. (2012) . Non Alignment in Footing, Intentionality and Dissent in Talk about Immigrants in Italy. Language and Communication, Vol. 32 (4), pp. 277-292.

Pincus, Fred L. (2006). Understanding Diversity: An Introduction to Class, Race, Gender, and Sexual Orientation. Boulder, London: Lynne Rienner Publishers.

Schmid, Carol L. (2001). The Politics of Language: Conflict, Identity, and Cultural Pluralism in Comparative Perspective. Oxford: Oxford University Press.

Sibai, Salam Adlbi. (2015). Narratives of Spanish Muslim Women on the Hijab as a Tool to Assert Identity. In La Barbera (Ed). Identity and Migration in Europe: Multidisciplinary Perspectives. New York: Springer, pp. 251-268.
Tetreault, Chantal. (2015) . Transcultural Teens: Performing Youth Identities in French Cités. Malden, MA: WileyBlackwell.

Torres, Rodolfo D., Miron, Louis F., and Inda, Jonathan Xavier. (1999). Race, Identity, and Citizenship: A Reader. New York: Blackwell Publishers.

Urcioli, Bonnie. (1996). Exposing Prejudice: Puerto Rican Experiences of Language, Race, and Class. Thousand Oak: Westview Press.

Valentine, Gill, Sporton, Deborah and Nielsen, Katrine Bang. (2009). The Spaces of Language: The Everyday Practices of Young Somali Refugees and Asylum Seekers. In Collins, James, Sembrouck, Stef and Baynham, Mike (Eds). Globalization and Language Contact: Scale, Migration, and Communicative Practices. London, New York: Continuum.

Vigouroux, Cecile, B. (2008). From Africa to Africa: Migration, globalization and language vitality. In Vigouroux, Cecile, $\mathrm{B}$ and Mufwene, Salikoko S (Eds). Globalization and Language Vitality: Perspectives from Black Africa. New York: Bloomsbury Academic, pp. 229254.

Vigouroux, Cecile B. (2009). Informal Economy and Language Practice in the Context of Migrations. In Collins, James, Sembrouck, Stef and Baynham, Mike (Eds). Globalization and Language Contact: Scale, Migration, and Communicative Practices. London, New York: Continuum.

Walter, Bronwen. (2000). 'Shamrocks Growing out of their Mouths': Language and the Racialisation of the Irish in Britain. In Kershen, Anne J. (Ed). Language and Migration. Burlington, Singapore, Sydney: Ashgate. 